\title{
Physiological, Nutritional, and Other Disorders of Tomato Fruit ${ }^{1}$
}

Stephen M. Olson²

Tomato producers run into many different fruit problems each year. This publication attempts to describe, give possible causes or explanations, and possible controls for certain of these tomato fruit problems.

\section{Blossom-End Rot}

Blossom-end rot (BER) is caused by a localized $\mathrm{Ca}$ deficiency in the developing fruit. It begins with light tan, water-soaked areas which can then enlarge and turn black and leathery in appearance (Figure 1). Most often the problem occurs at the blossom end of the fruit, but on occasion can occur on the side of the fruit (Figures 2 and 3). It may also occur internally with no visible symptoms on outside of fruit (Figure 4). Many factors can influence BER. The following conditions may increase BER: low soil $\mathrm{Ca}$, high $\mathrm{N}$ rates, using ammoniacal sources of $\mathrm{N}$, high concentrations of soluble $\mathrm{K}$ and $\mathrm{Mg}$ in the soil, high salinity, low humidity, inadequate soil moisture, excess soil moisture, damage to root system by nematodes, disease, mechanical means or heavy pruning. In greenhouse production not cycling the irrigation system at night can increase BER, since night is an important time of Ca uptake. In Florida, adequate soil $\mathrm{Ca}$ is considered to be $300 \mathrm{ppm}$ or higher by Mehlich-1 index. Foliar applications of $\mathrm{Ca}$ materials have not proven to reduce BER, since very little $\mathrm{Ca}$ is taken up by the fruit and that taken up by the leaves can not be translocated to the fruit. Prevent with proper fertilization and good water management.

\section{Catface}

Catfacing is a generic term used to describe a tomato fruit that has a gross deformity and is usually not marketable. The defect is usually located on the blossom end of the fruit (Figures 5 and 6). The deformity is caused by something (internal or external) that occurs during the formation of the flower that results in the fruit not developing normally. There is little published information as to the exact cause and there actually may be more than a single cause. Cool or cold temperatures that occur about 3 weeks before bloom can increase the amount of catfacing. In general, jointless varieties are more prone to catfacing than jointed varieties. Heavy pruning in indeterminate varieties has been shown to increase catfacing but this has not been shown to happen in our short-stake varieties. In indeterminate

1. This document is HS-954, one of a series of the Department of Horticultural Sciences, Florida Cooperative Extension Service, Institute of Food and Agricultural Sciences, University of Florida. Publication date: February 2004. Please visit the EDIS website at http://edis.ifas.ufl.edu.

2. Dr. Stephen M. Olson, professor, Department of Horticultural Sciences, North Florida Research and Education Center, Quincy. Cooperative Extension Service, Institute of Food and Agricultural Sciences, Univeristy of Florida, Gainesville, 32611.

The Institute of Food and Agricultural Sciences (IFAS) is an Equal Employment Opportunity - Affirmative Action Employer authorized to provide research, educational information and other services only to individuals and institutions that function without regard to race, creed, color, religion, age, disability, sex, sexual orientation, marital status, national origin, political opinions or affiliations. For information on obtaining other extension publications, contact your county Cooperative Extension Service office. Florida Cooperative Extension Service / Institute of Food and Agricultural Sciences / University of Florida / Larry R. Arrington, Interim Dean 
varieties, catfacing is thought to be related to reduction in auxins in the plant from removing the growing points. Drifts of herbicides such as 2,4-D can cause fruit to catface (Figure 7). Heavy thrips feeding on young fruit can cause a type of catfacing, also fruit on plants that are mildly affected by Tomato Little Leaf (See EDIS Publication HS-883 for more information) are severely catfaced (Figure 8). There is not much that can be done for control. Varieties should be selected that historically have had little problem with catfacing. Try to prevent spray drift from undesirable chemicals and in the case of little leaf, prevent soils from becoming waterlogged.

\section{Cracking}

Two different forms of cracking occur in tomato fruit (Figure 9). Radial cracking originates from the stem end and progresses toward the blossom end. Concentric cracking occurs in a ring or rings around the stem scar. It is possible to have both types on the same fruit. Cracking occurs when the internal expansion is faster than the expansion of the epidermis and the epidermis splits. Varieties differ greatly in their susceptibility to cracking. Cracking can occur at all stages of fruit growth but as fruit matures they become more susceptible, especially as color develops. The more resistant a variety is, the later in maturity of the fruit cracking may occur. Control is through selecting tolerant varieties or by reducing fluctuations in soil moisture. Cracking may also be reduced by maintaining good foliage cover, since exposed fruit are more susceptible. Wide fluctuation in air temperature can also increase cracking. Cracking is more of a problem in a vine-ripe operations than in a mature-green operation.

\section{Graywall (Blotchy Ripening)}

Internally graywall is characterized by dark necrotic areas usually in the vascular tissue of the outer walls (Figures 10 and 11). The necrosis is sometimes present in the cross-walls and very infrequently in the center pith area of the fruit (Figure 12). Outward symptoms show up as grayish appearance caused by partial collapse of the wall tissue; hence the term graywall. It typically develops on green fruit prior to harvest but can develop later.
Fruits affected are typically not marketable due to blotchy appearance as fruit ripens. Cause is not completely understood. There are variety differences in susceptibility. Graywall is more of a problem during cool and short days. High $\mathrm{N}$ may increase the problem and adequate $\mathrm{K}$ may reduce the problem.

\section{Internal White Tissue}

Fruit affected by this disorder usually show no outward symptoms. When ripe fruits are cut, white hard areas especially in the vascular region are present in the outer walls (Figure 13). Under severe conditions, fruit may also show white tissue in cross-wall and center of fruit. The problem is more of a concern with vine-ripe or u-pick production since fruit picked mature-green and gassed rarely show the problem. High temperatures during the ripening period in the field seem to trigger the symptoms. Adequate $\mathrm{K}$ fertilization has shown to reduce but may not eliminate it. Some varieties are more resistant to the problem, especially the high colored varieties. The problem at times may be so severe that fruits are unmarketable.

\section{Irregular Ripening}

Irregular ripening is a fruit ripening disorder caused by feeding of nymphs of the Silverleaf whitefly (Bemisia argentifolii) (Figure 14) on the tomato foliage. Green fruit show no symptoms but as fruit ripens, color fails to develop uniformly (Figure 15). Color often develops along locule walls with intermediate areas remaining green or yellow, producing a star-burst appearance. With sufficient time, nearly normal external color develops on most fruit but internal areas remain hard with little or no color development. Fruit affected are unmarketable. Irregular ripening can occur with as few as four Silverleaf whitefly nymphs (Figure 16) per terminal leaf. This disorder can be controlled if nymphs are controlled. Silverleaf whiteflies derive their name from damage they do to foliage of squash plants(Cucurbita pepo L.) (Figure 17).

\section{Pox and Fleck}

In most cases when a fruit is affected both disorders are found together but are considered separate problems (Figure 18). Pox is described as 
small cuticular disruptions found at random on the fruit surface (Figure 19). The number can vary from a few to many. Fleck, also known as Gold Fleck, develops as small irregular shaped green spots at random on the surface of immature fruit which become a gold in color as fruit ripens (Figures 20 and 21). Number of spots can vary from few to many. Fruits severely affected with pox and fleck are not marketable. Both conditions seem to be genetic in nature, but are difficult to breed out of a variety since the disorders only show up under certain environmental conditions. There seems to be some differences of opinion as to the conditions inducing this problem. There are differences between varieties as to susceptibility to pox and fleck.

\section{Puffiness}

When this problem is slight, it may be impossible to detect puffiness until fruit are cut (Figure 22). Severe puffy fruit will appear to be flat-sided or angular in nature (Figure 23). When fruit are cut, open cavities are observed between the seed gel area and the outer wall (Figure 24). Fruits are also very light in relation to size. This problem is caused by any factor that affects fruit set. Including inadequate pollination, fertilization, or seed development (Figure 25). Most common causes in Florida are too low or high temperatures during fruit set. Use of "hot set" varieties can reduce the problem but even these have limitations when night temperatures remain above about $75^{\circ} \mathrm{F}$. Other factors such as high $\mathrm{N}$, low light, or rainy conditions can also cause seed set problems.

\section{Rain Check}

Rain check can be described as tiny cracks that develop on the shoulder of the fruit. These cracks can vary from just a few to almost complete coverage of the shoulder (Figure 26). The cracks feel rough to the touch and affected areas can take on a leathery appearance and not develop proper color as fruit ripens. Green fruits are most susceptible, followed by breakers and are not affected at all. Damage occurs most often on exposed fruit after a rain. Exact cause is not known, but appears to be related to exposure of the fruit to water. The problem is more severe when heavy rains occur after a long dry period. There are differences among varieties to susceptibility to rain check. Also, varieties with good leaf coverage usually have less rain check.

\section{Sunscald}

Sunscald can be broken down into 2 types, sub lethal (Figure 27) and lethal (Figure 28). Sub lethal sunscald can be described as a yellow, hard area usually on the shoulder of the fruit. This occurs when tissue temperature rises above about $86^{\circ} \mathrm{F}$. The high tissue temperature will not allow the red pigment to develop nor the flesh to soften but allows the yellow pigments to develop. With lethal sunscald, the tissue turns white and dies. Many times the dead tissue will turn black from fungi that are feeding on the dead tissue. Lethal sunscald occurs when tissue temperatures rise above $104^{0} \mathrm{~F}$. Damage usually occurs when fruits are suddenly exposed to sunlight. This most frequently occurs after a harvest or a storm when leaves are moved around and fruit exposed. Over pruning can also increase sunscald problems especially with fruit in the upper part of the plant. Also good spray programs to ensure good foliage cover can reduce the problem. Growers at times may use a sun screen material such as Snow or Surround to help reduce sunscald.

\section{Tomato Spotted Wilt Fruit Damage}

When infection occurs early in season, fruit fail to set or are severely deformed and may have cracks or concentric rings on fruit (Figure 29). If disease hits later in season it may be impossible to see any damage on green fruit, but after ripening, yellow rings or blotches may show up rendering the fruit unmarketable (Figure 30). This is a severe problem when fruit are picked mature green, gassed and shipped out, since the discoloration may not appear until fruits reaches terminal market and the load is rejected because of discolored fruit (Figure 31). The discoloration is only on the surface and center of fruit will ripen normally. Control of fruit problems is through control of the virus or vector. Research has shown that control of primary infection is not possible with insecticides but control of secondary infection is possible through good spray schedule and selection of materials that will control thrips. Recent research has shown that primary infection can be 
reduced with production on highly UV-reflective (metalized) mulches and use of Actigard in production system. Resistant varieties are available but at times the foliage may not show symptoms but the fruit may, rendering it unmarketable.

\section{Western Flower Thrips Oviposition Damage}

This injury is characterized by a small dimple often with a white halo around the dimple (Figure 32). The injury is caused by the female Western Flower Thrips (Frankliniella occidintalis) (WFT) (Figure 33) inserting an egg into the fruit when the fruit is very small. Many times the bloom has not yet shed the corolla when the injury occurs. The number of dimples can vary from a few to very many (Figure 34). Numerous dimples can result in the fruit being reduced in grade. Damage is mostly on the surface and does not go very deep into the fruit (Figure 35). Dimple does persist throughout the life of the fruit but the halo area may go away when fruit ripens (Figure 36). Control is through management of WFT.

\section{Zebra Stripe}

Zebra stripe can be characterized as a series of dark green spots arranged in a line from the stem end to the bloom end (Figure 37). At times it seems the spots coalesce together and form elongated markings (Figure 38). Many times the dark green areas will disappear when fruit ripens. This problem seems to be variety related. It is probably a genetic defect that only develops under certain environmental conditions. Zebra stripe may be linked to pox and fleck.

\section{Zippering}

Zippering is described as a fruit having thin scars that extend partially (Figure 39) or fully (Figure 40) from the stem scar area to the blossom end. The longitudinal scar has small transverse scars along it (Figure 40). At times there may be open holes in the locules in addition to the zipper scar (Figure 41). Usually an anther that is attached to the newly forming fruit causes the zipper scar. Some people feel that a zipper is formed when the "blooms" stick to the fruit and do not shed properly but this may not be a cause. The only control is to select varieties that are not prone to zippering.

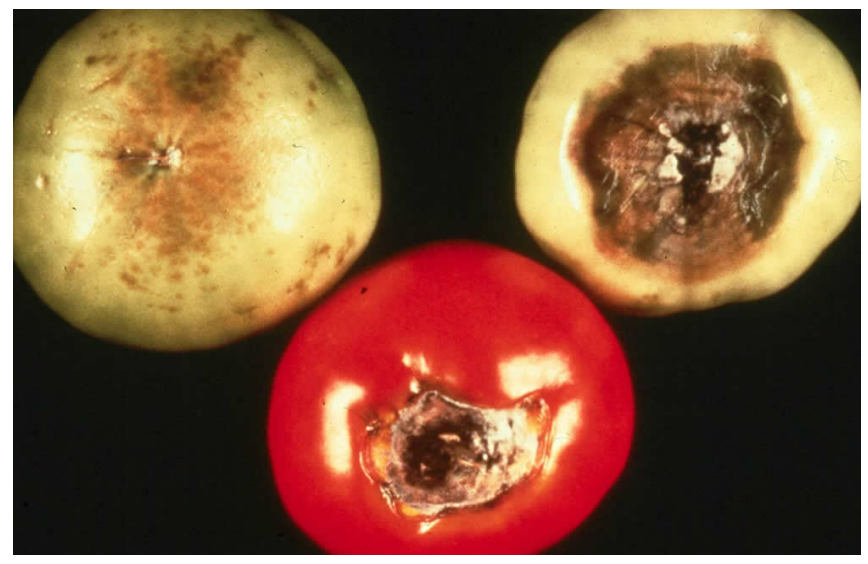

Figure 1. Fruit showing symptoms of BER, top left fruit showing mild BER, others showing severe.

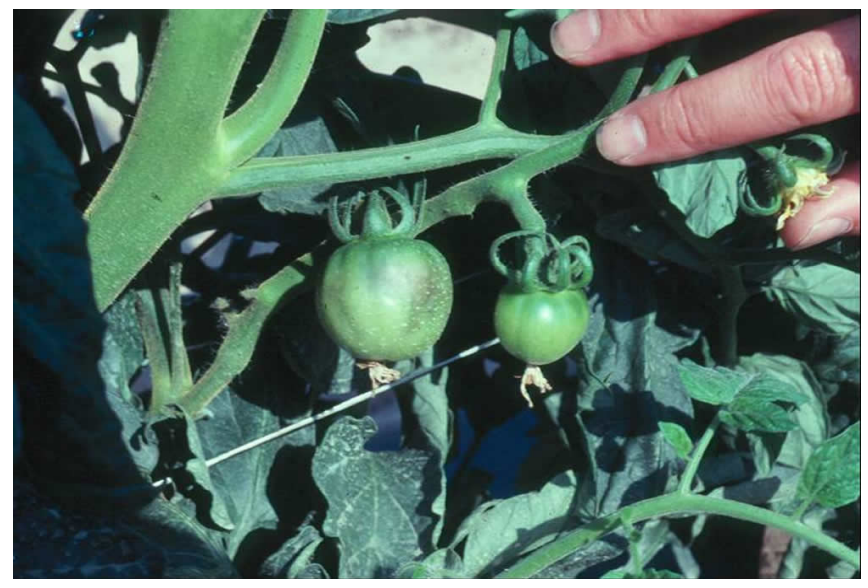

Figure 2. Fruit on plant showing BER on sidewall.

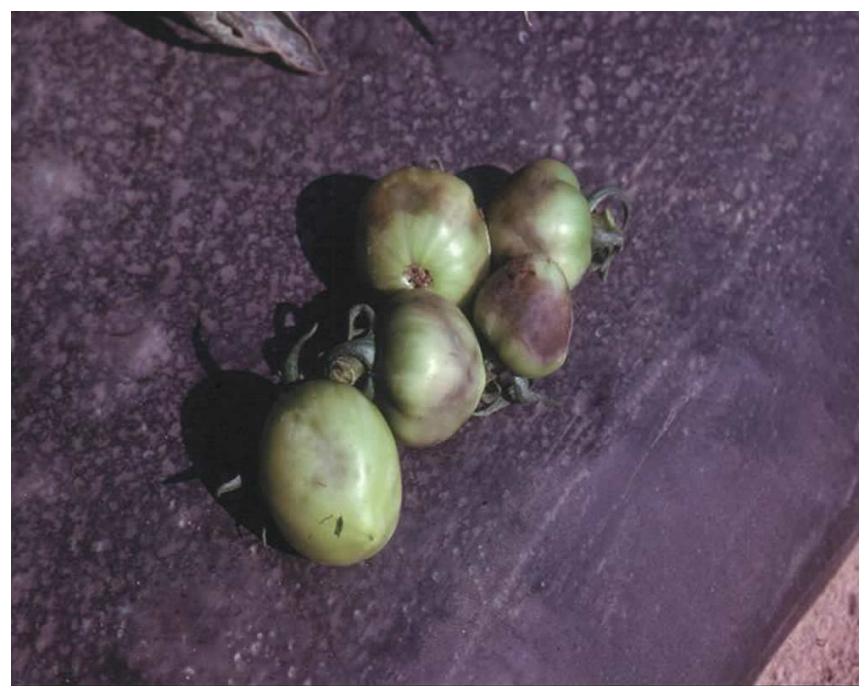

Figure 3. Several fruit showing sidewall BER. 


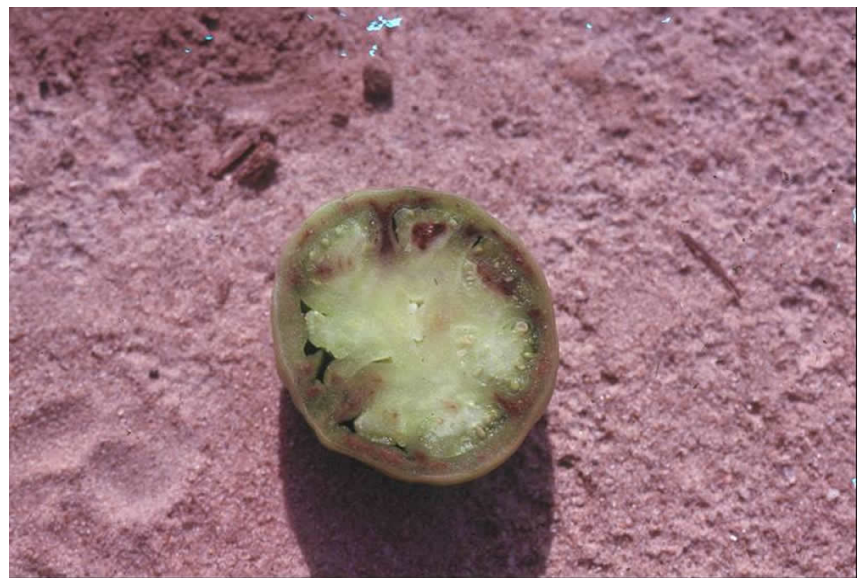

Figure 4. Cross section of fruit showing internal BER.

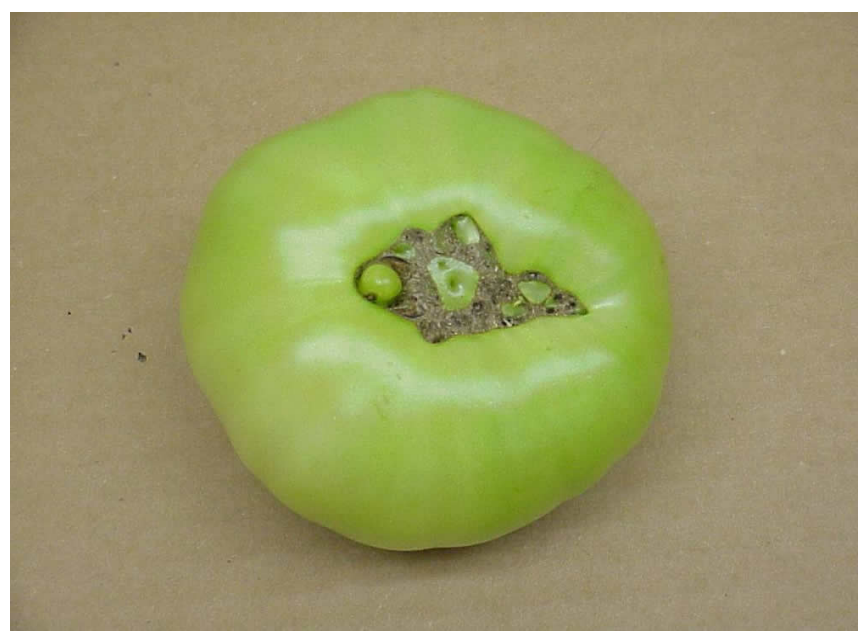

Figure 5. Fruit showing catfacing on blossom end.

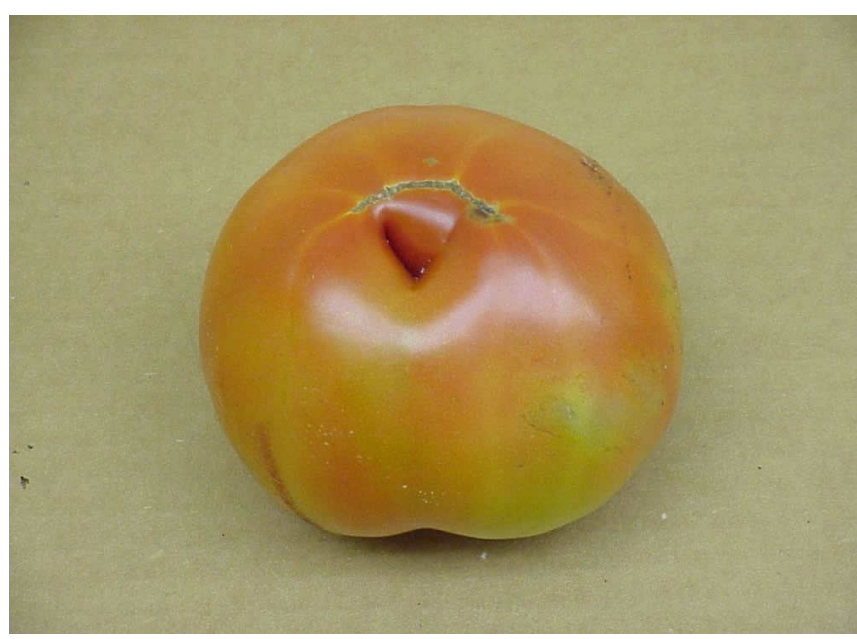

Figure 6. Catfaced fruit with hole into fruit.

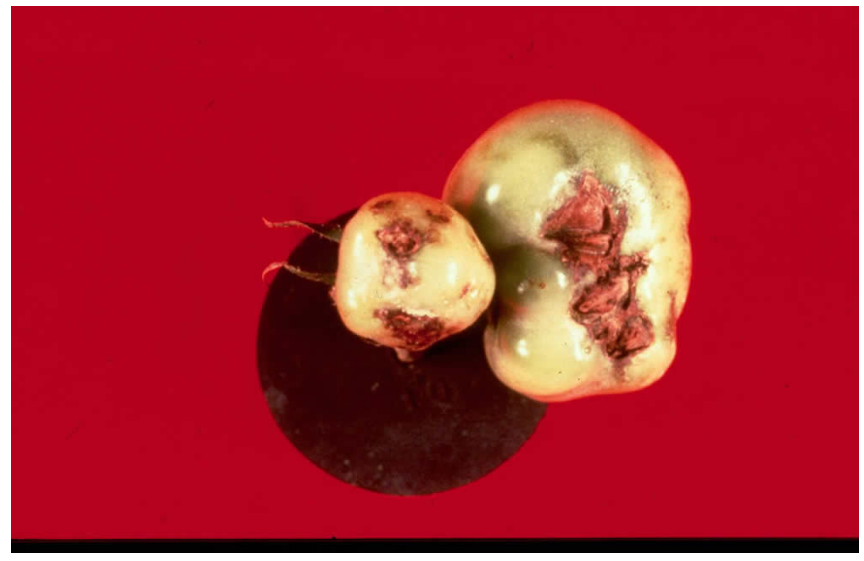

Figure 7. Fruit damage due to exposure to 2, 4-D.

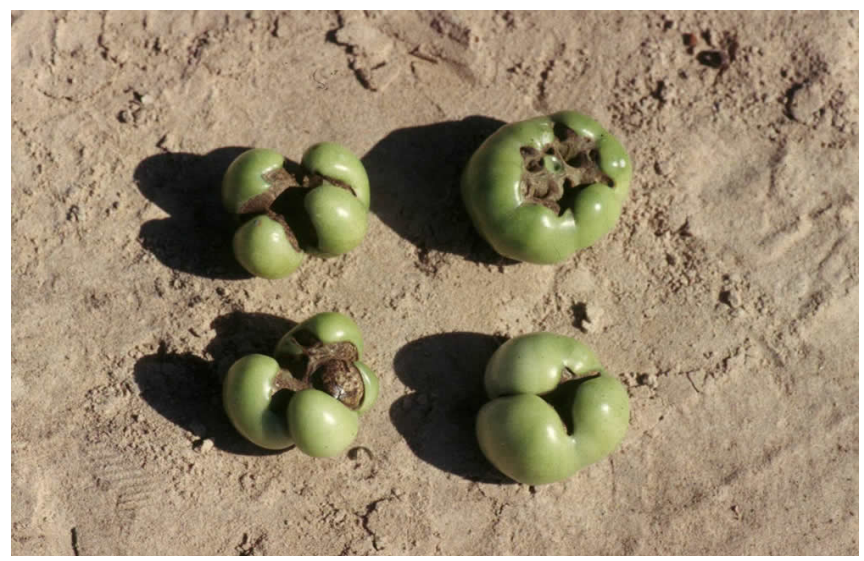

Figure 8. Distorted fruit due to Little Leaf.

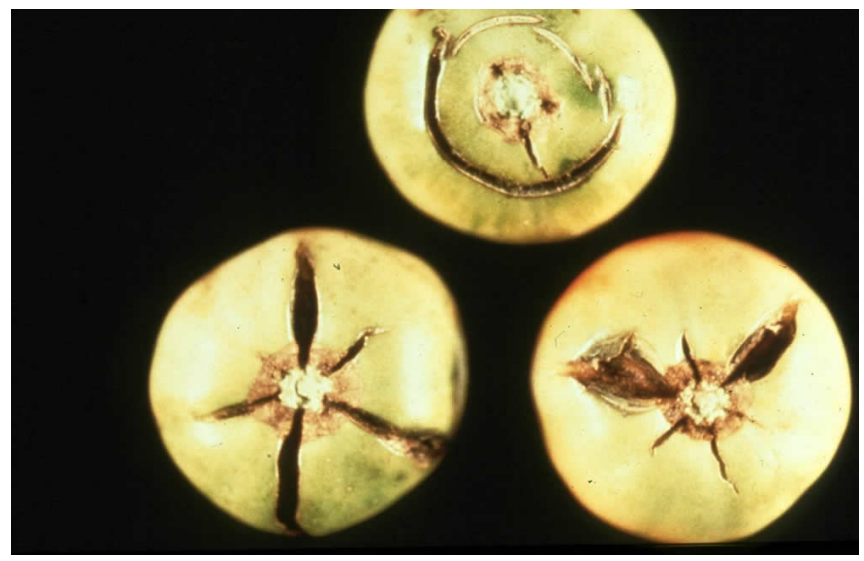

Figure 9. Fruit showing both radial and concentric cracking. 


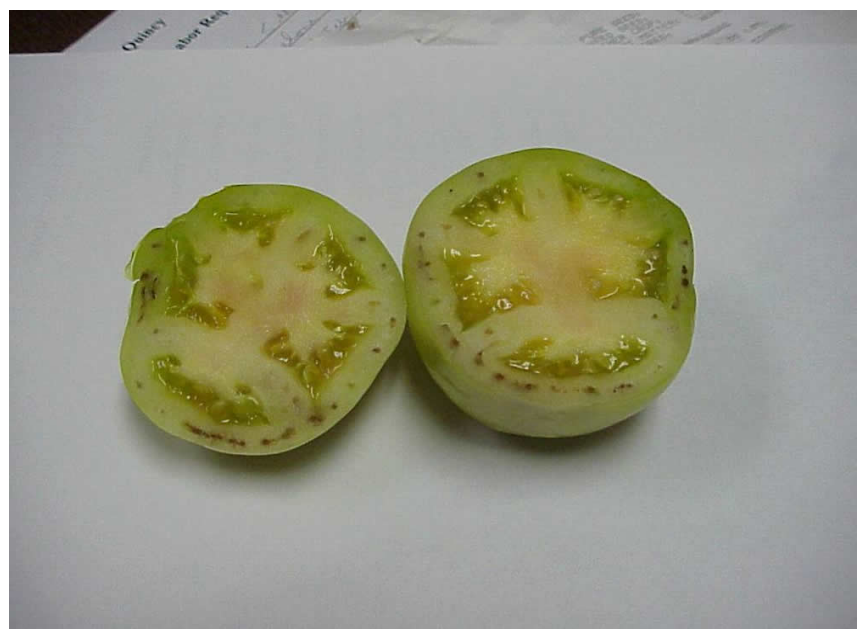

Figure 10. Fruit showing graywall necrotic areas.

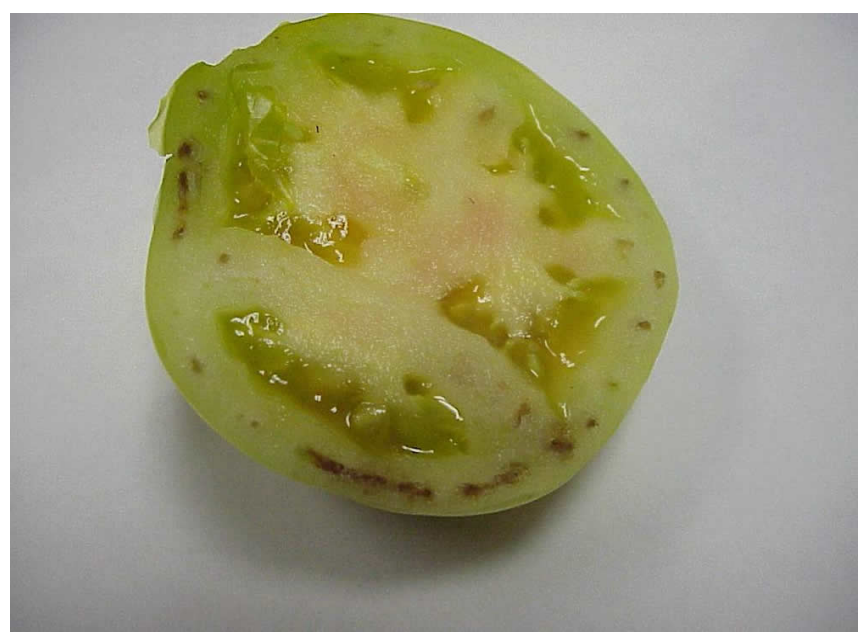

Figure 11. Closeup of graywall in fruit walls.

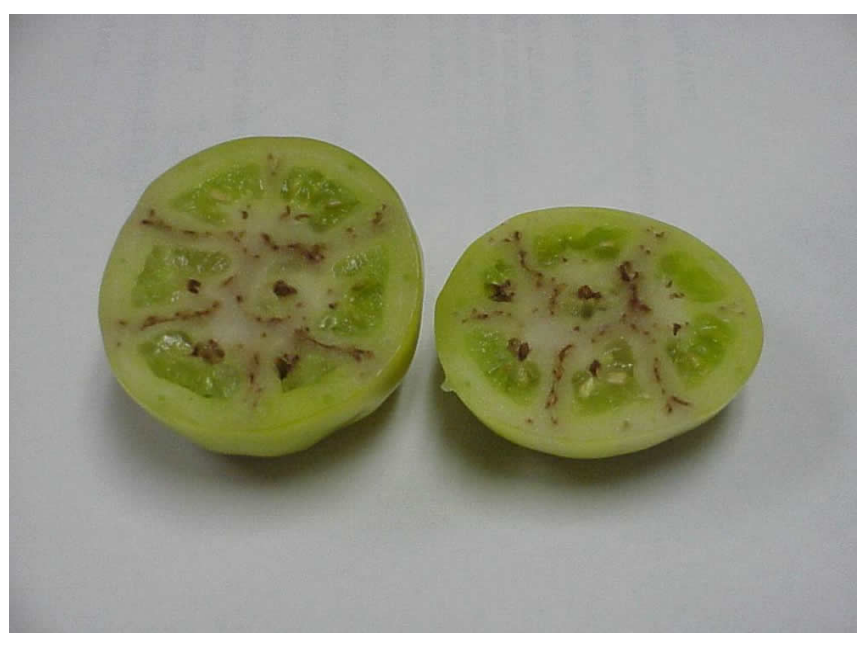

Figure 12. Fruit showing graywall in center pith area.

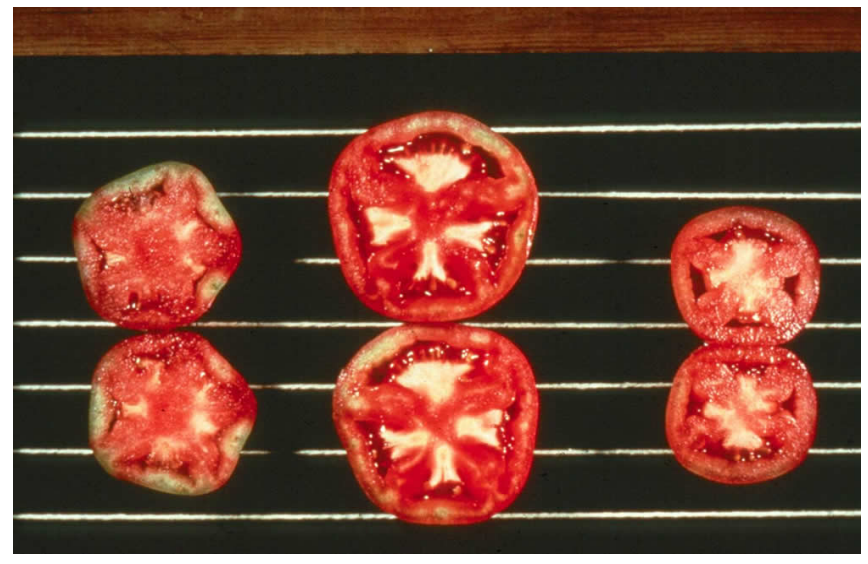

Figure 13. Fruit showing internal white tissue in walls and center.

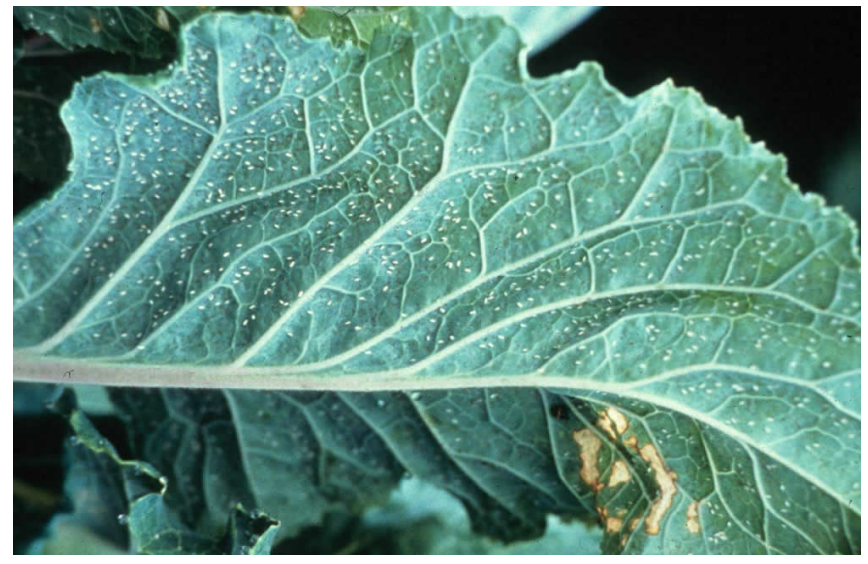

Figure 14. Adult silverleaf whiteflies feeding on collard leaf.

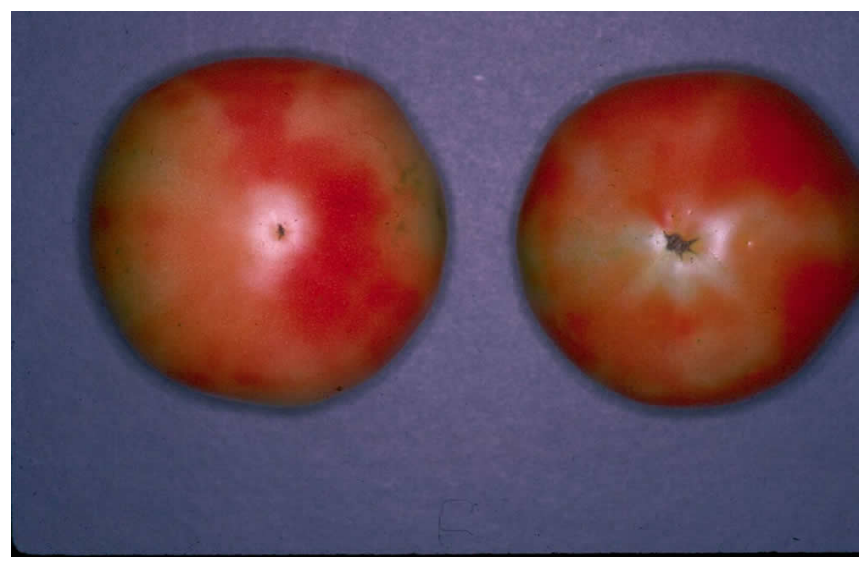

Figure 15. Fruit showing symptoms of irregular ripening. 


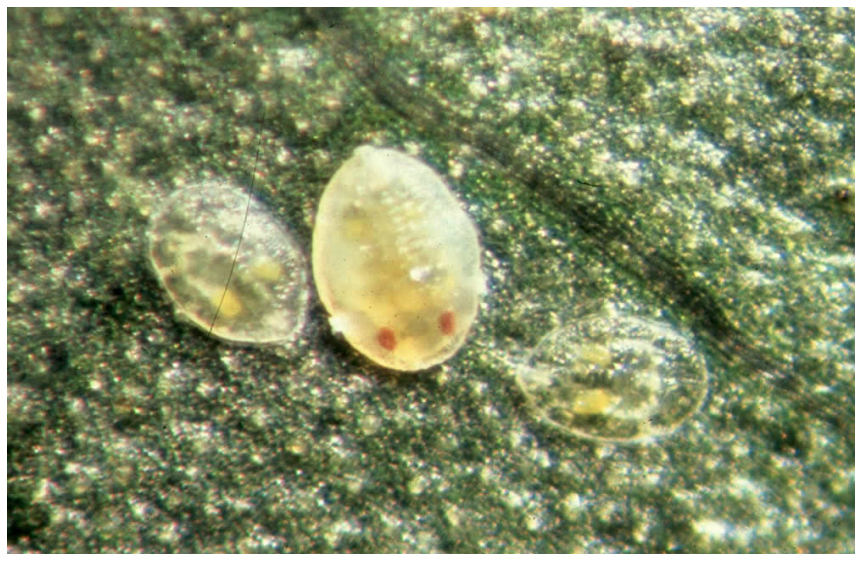

Figure 16. Silverleaf nymph next to pupa (note red eyes).

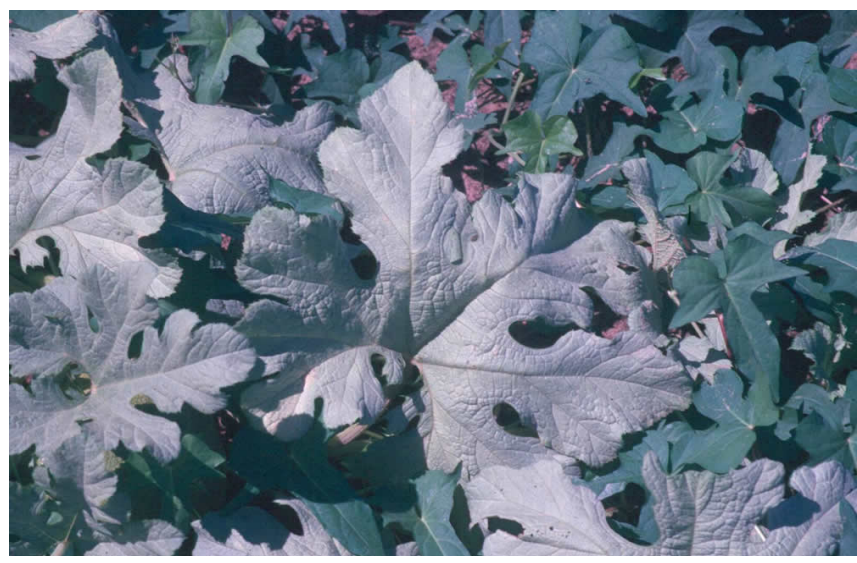

Figure 17. Pumpkin leaves turned silver by feeding of silverleaf whiteflies.

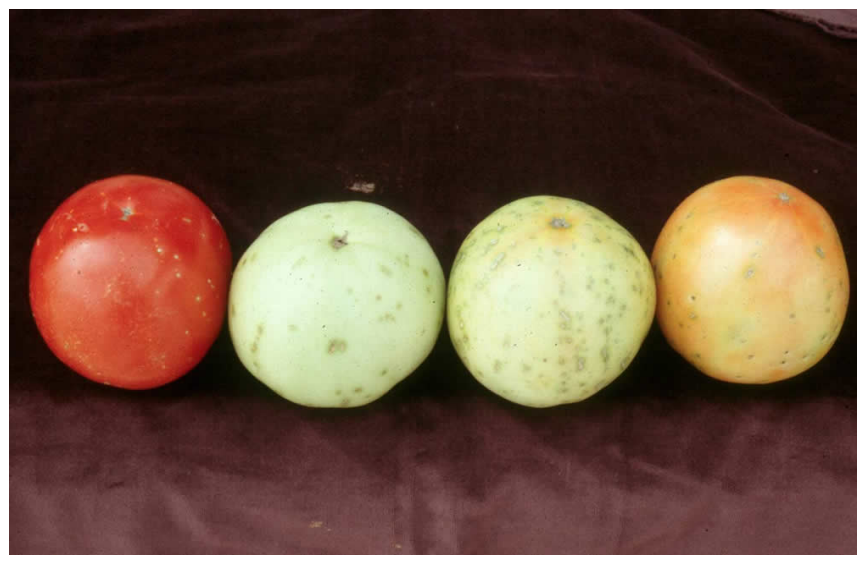

Figure 18. Several fruit showing severe pox and flex.

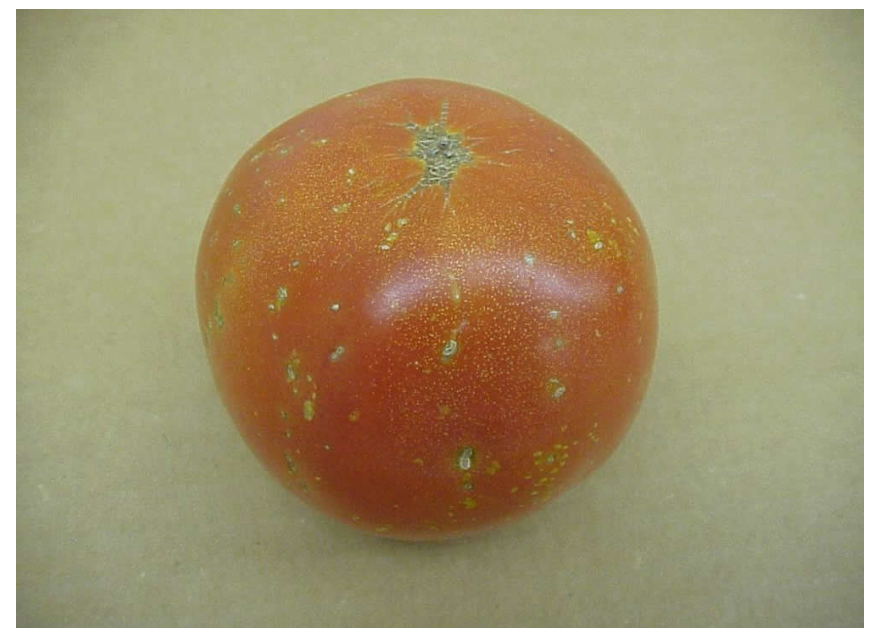

Figure 19. Note pox disruptions on fruit.

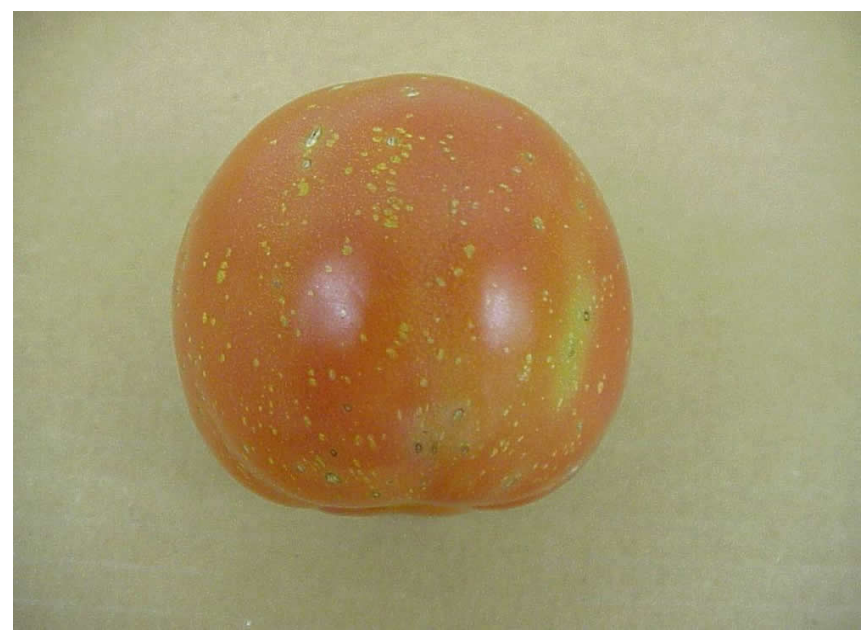

Figure 20. Note gold areas on fruit.

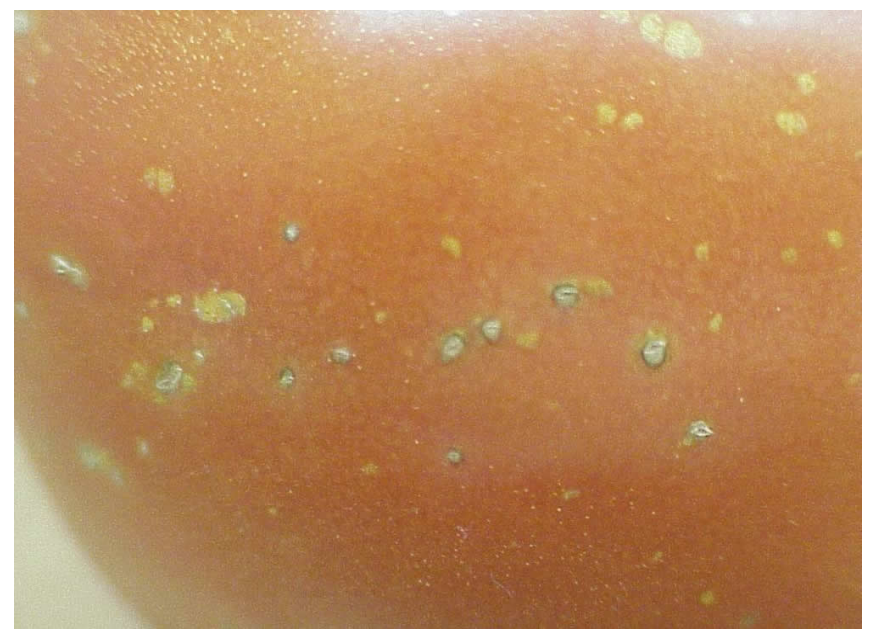

Figure 21. Closeup of pox and flex. 


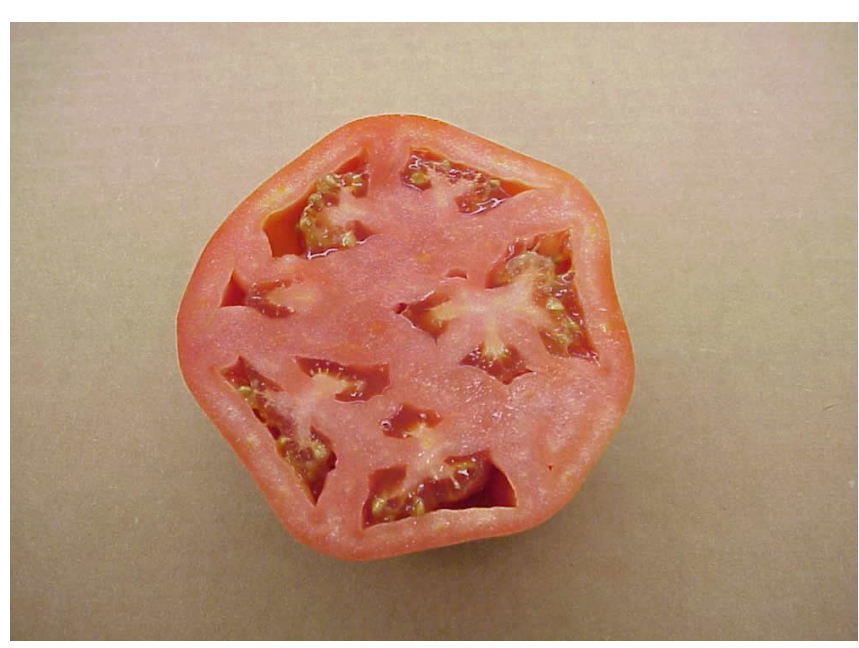

Figure 22. Fruit mildly affected by puffiness, note slight open areas.

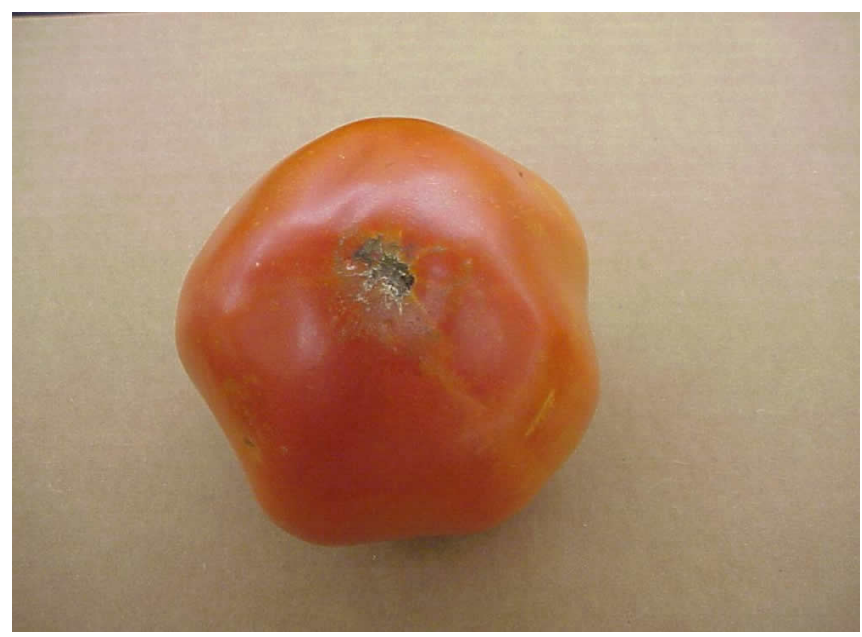

Figure 23. Note flattened areas on sidewalls of fruit caused by puffiness.

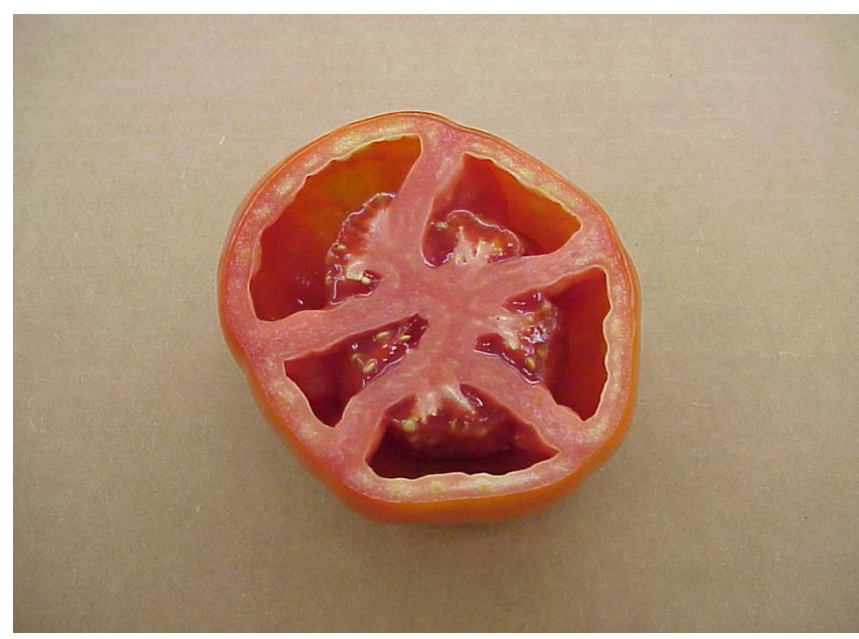

Figure 24. Fruit severely affected by puffiness, note large open areas.

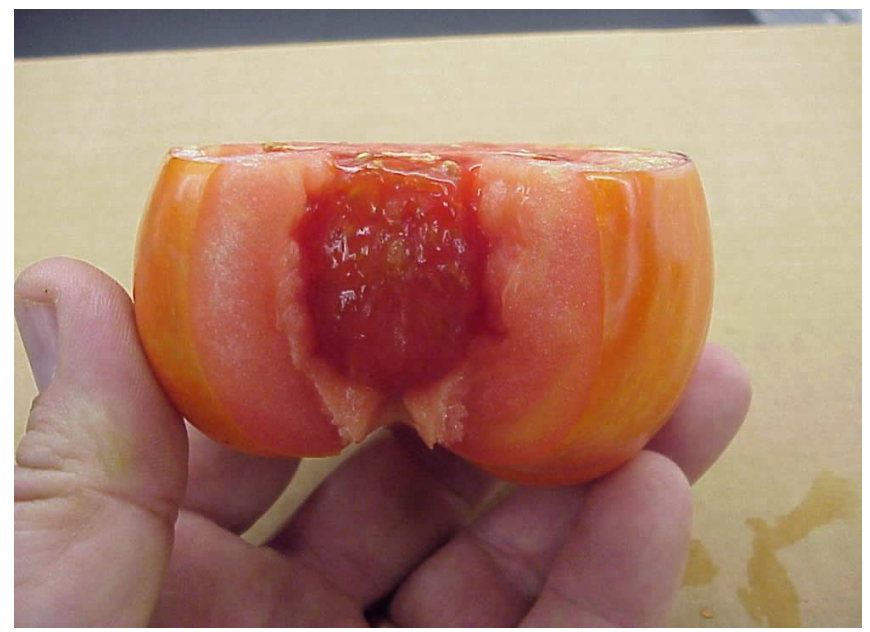

Figure 25. Note absence of seed in gel area caused by puffiness.

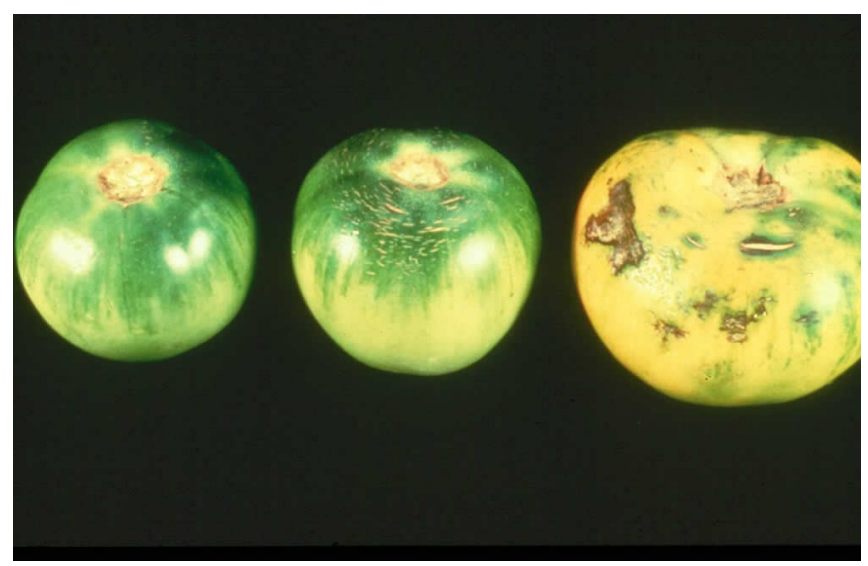

Figure 26. Fruit with severe rain check on right side and good fruit on left side, fruit in center has slight problem.

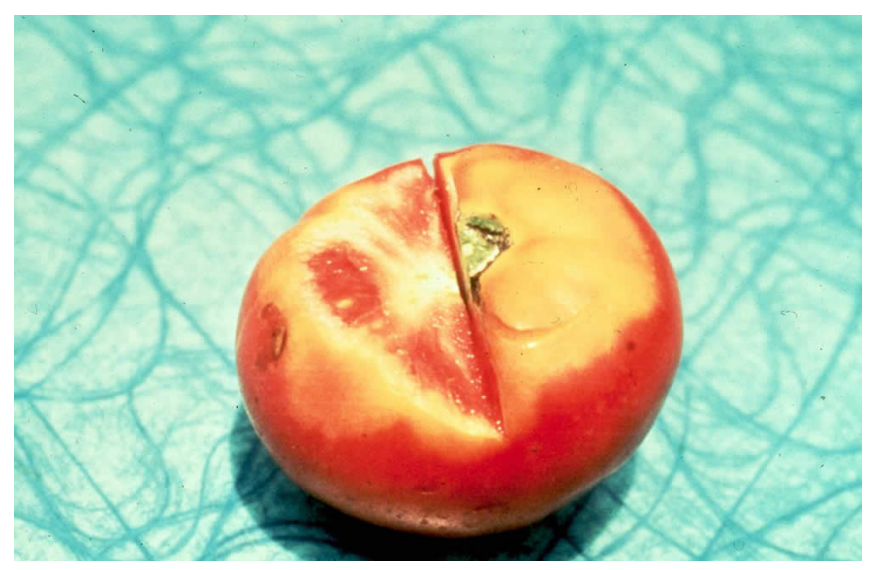

Figure 27. Sublethal sunscald, note yellow tissue but no collapse. 


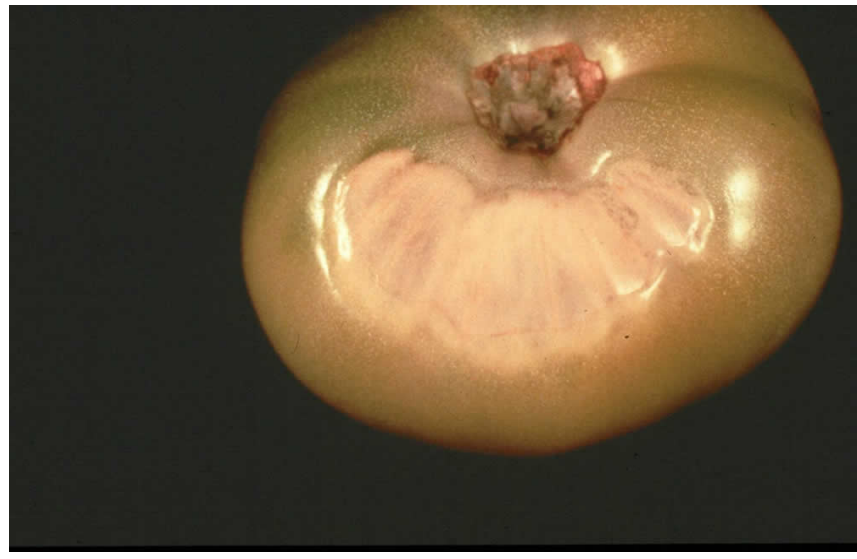

Figure 28. Lethal sunscald, note sunken area.

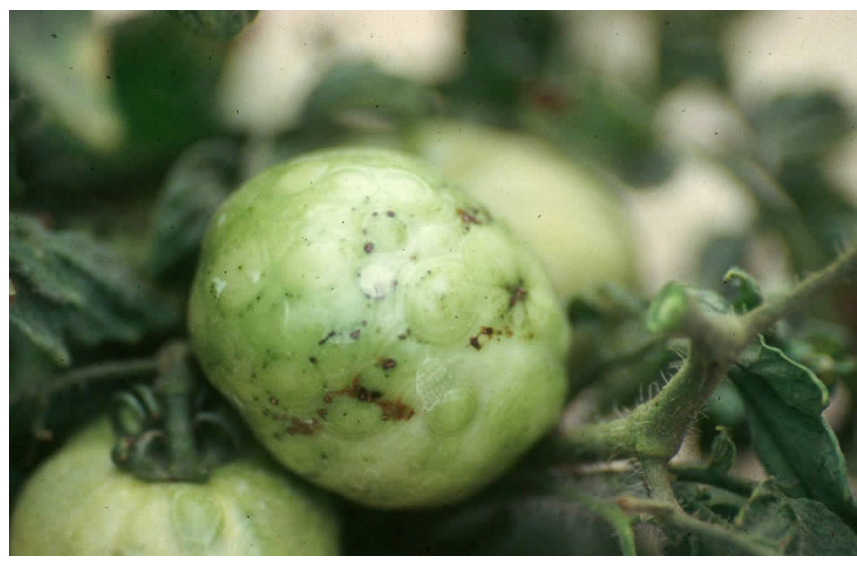

Figure 29. Fruit severely affected by TSW.

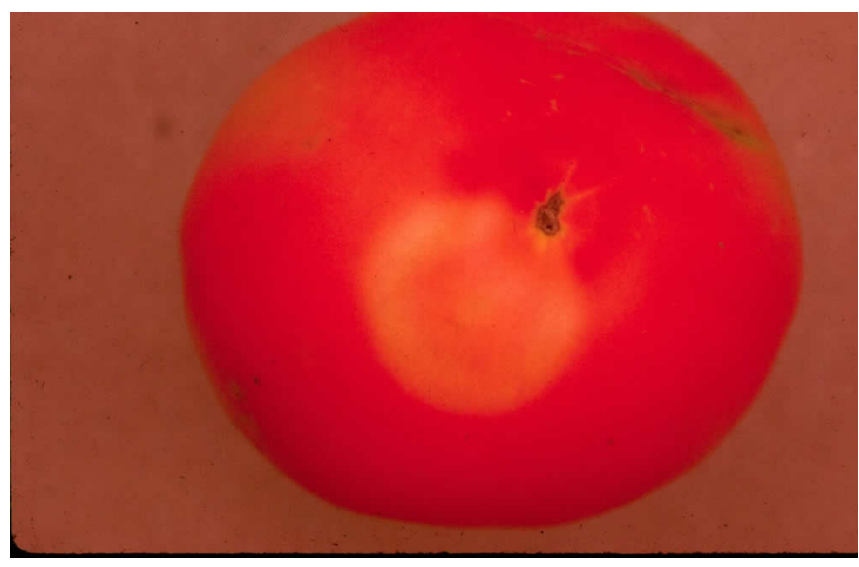

Figure 30. Fruit mildely affected by TSW.

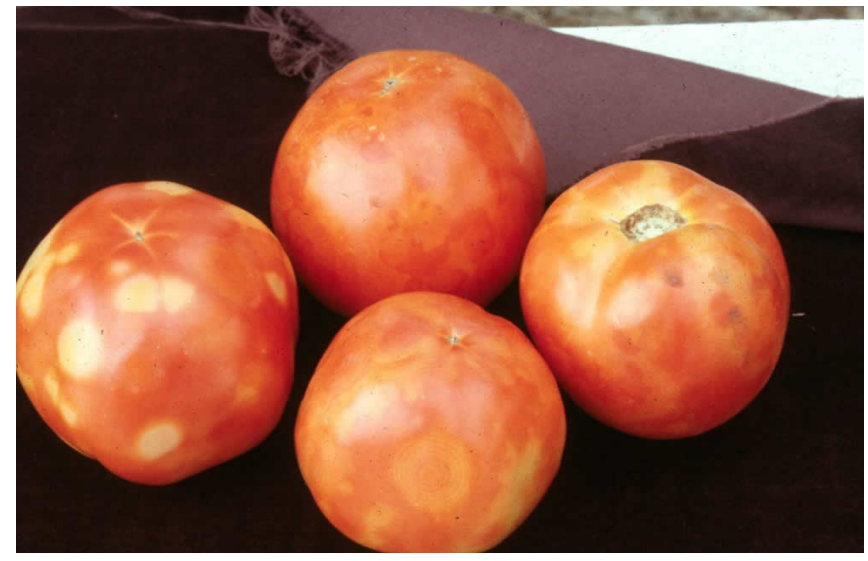

Figure 31. Fruit that showed TSW symptoms after gassing.

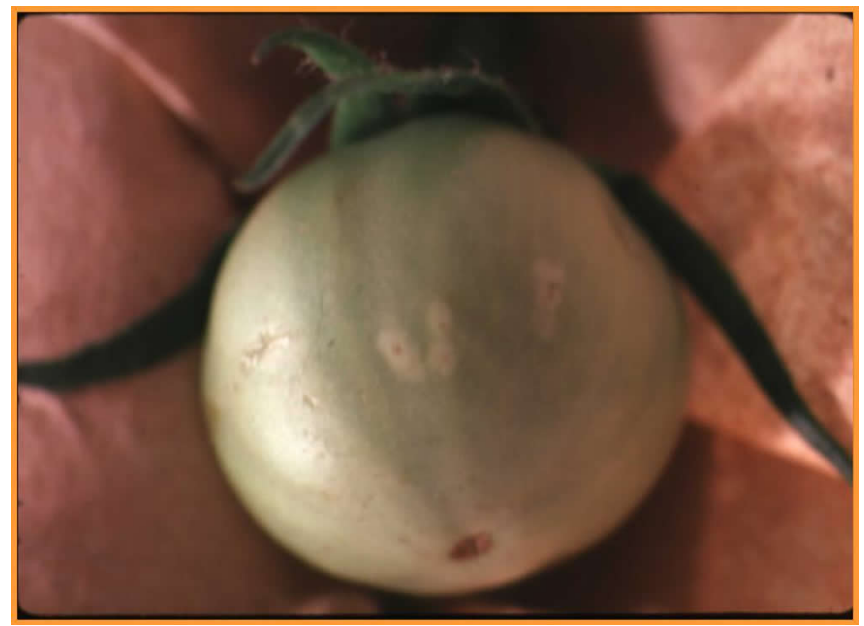

Figure 32. Fruit showing oviposition damage by Western Flower Thrips with halo around it.

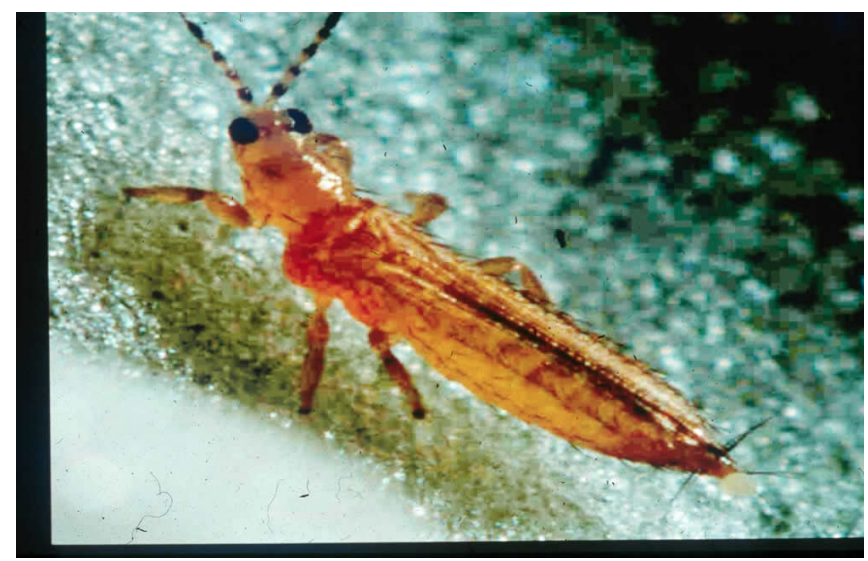

Figure 33. Adult Western Flower Thrips. 


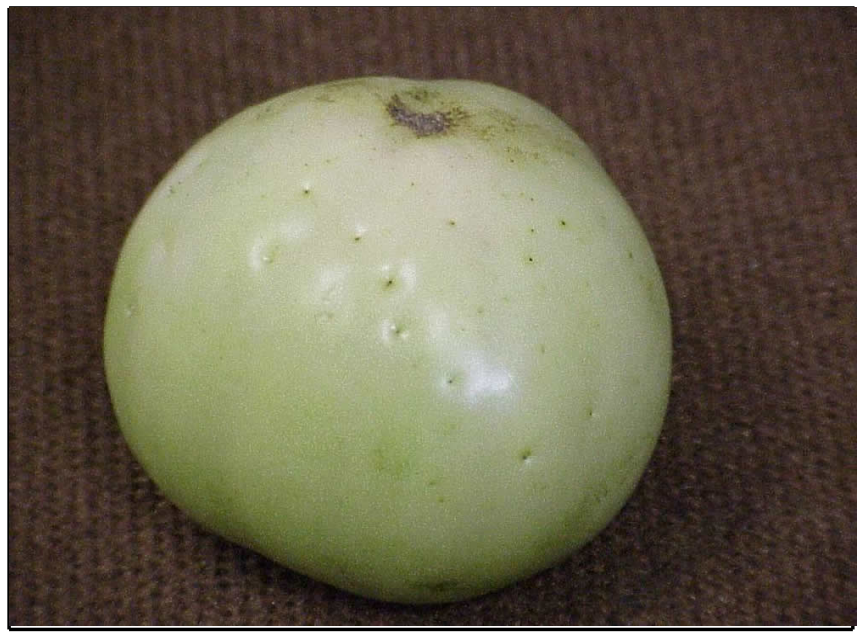

Figure 34. Fruit showing numerous oviposition dimples.

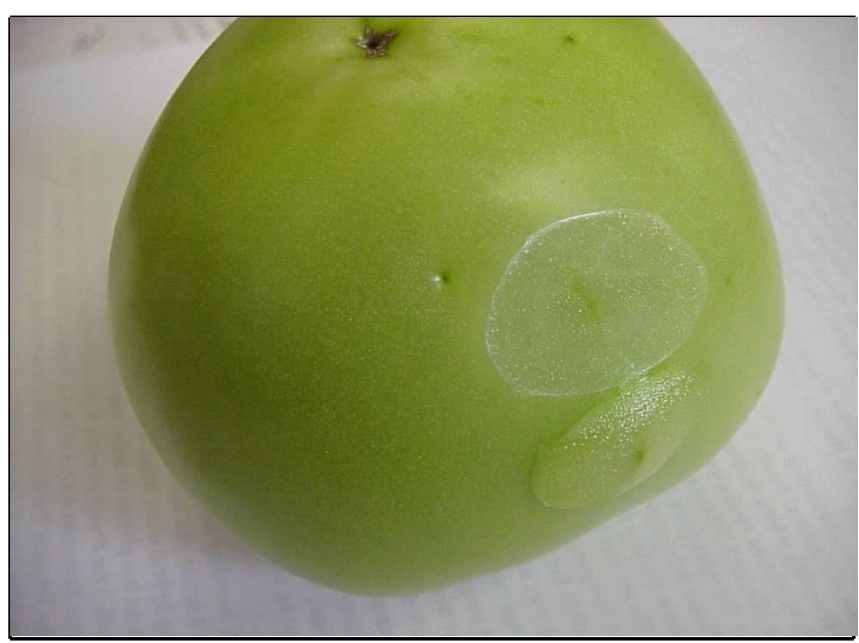

Figure 35. Damage from oviposition dimple does not go deep into fruit.

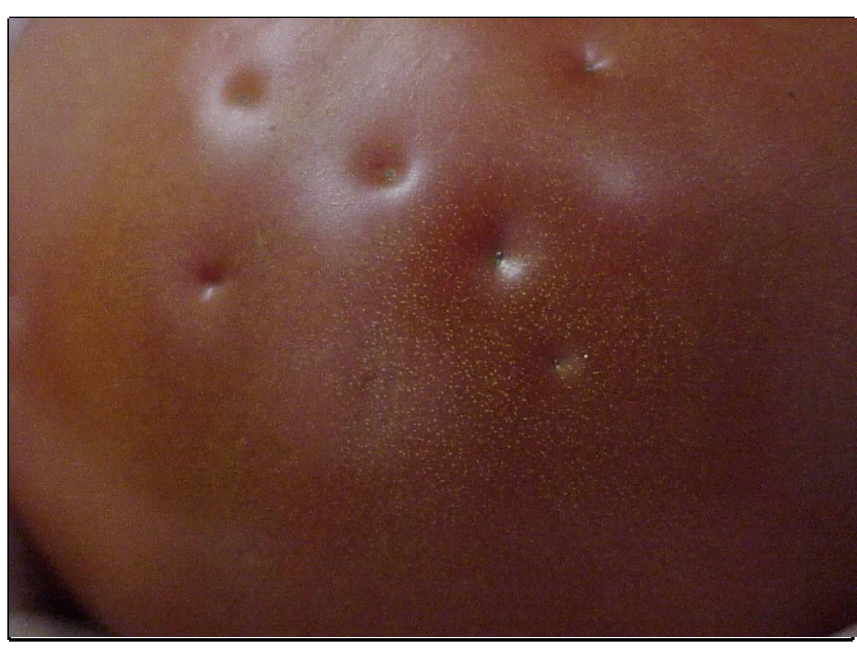

Figure 36. Oviposition dimples persisting on ripe fruit.

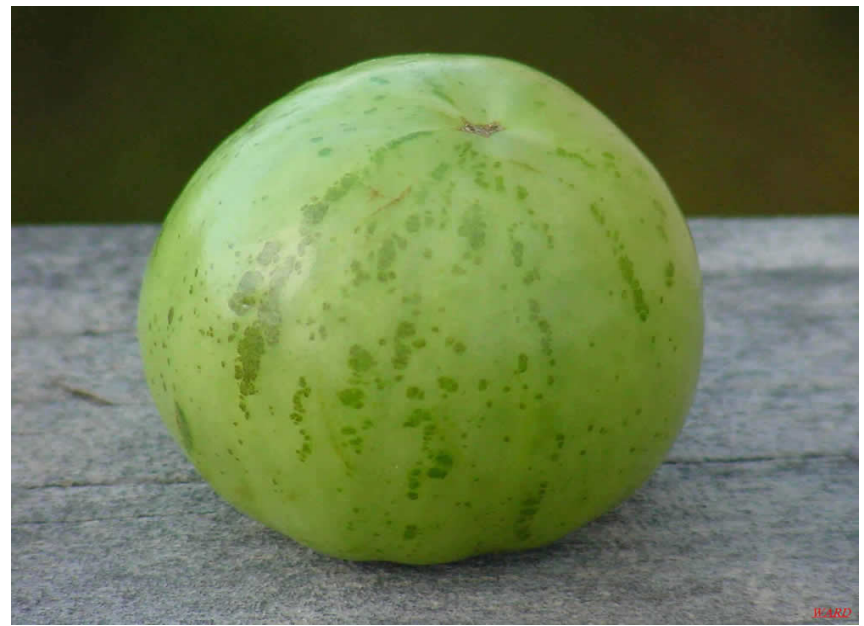

Figure 37. Zebra stripe spots on fruit.

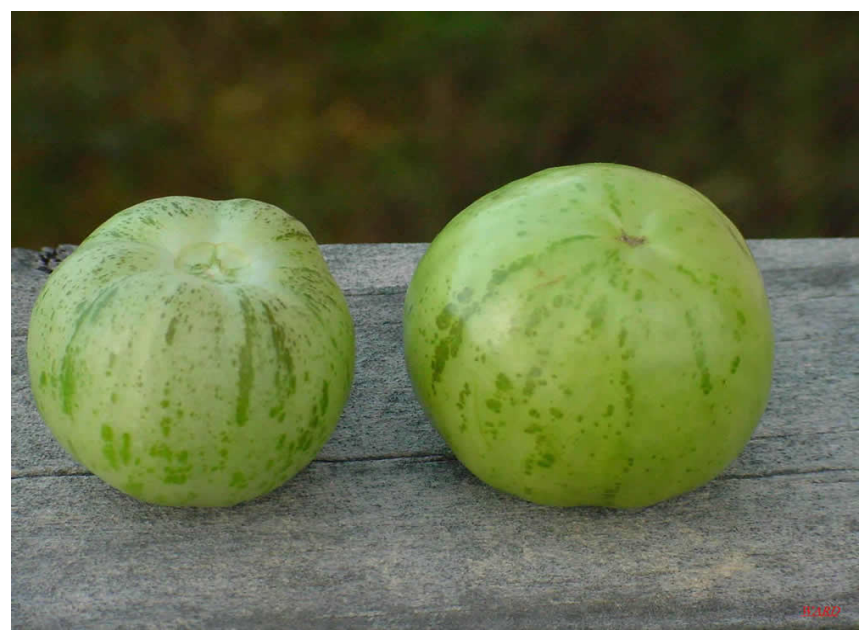

Figure 38. Zebra stripe spots may form elongated areas.

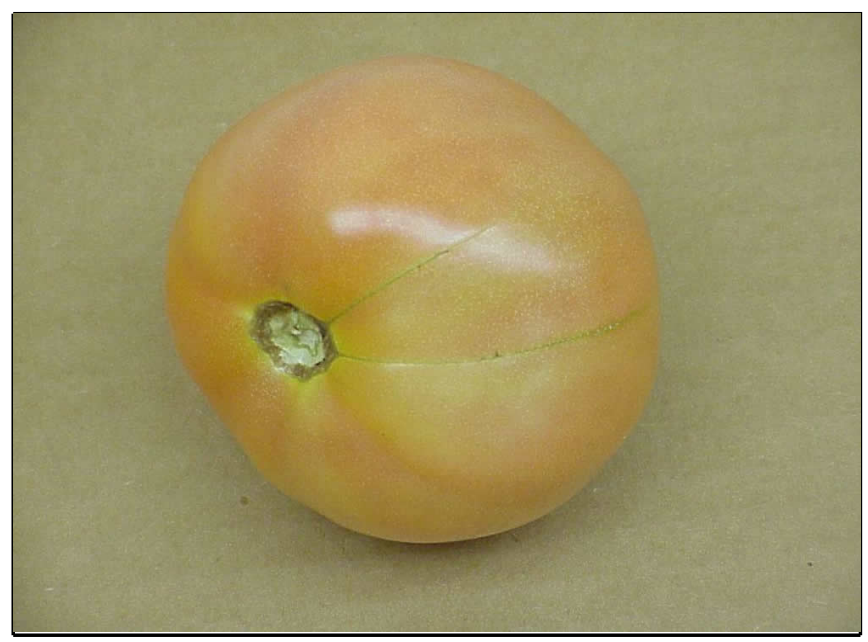

Figure 39. Slight zippering on fruit. 


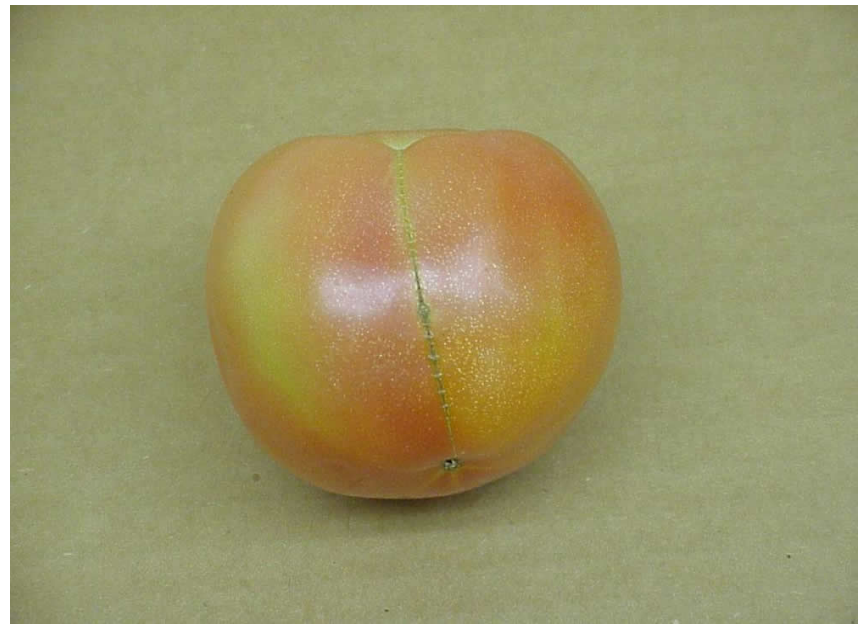

Figure 40. Zippering going from stem end of fruit to blossom end, note transverse scars on zipper.

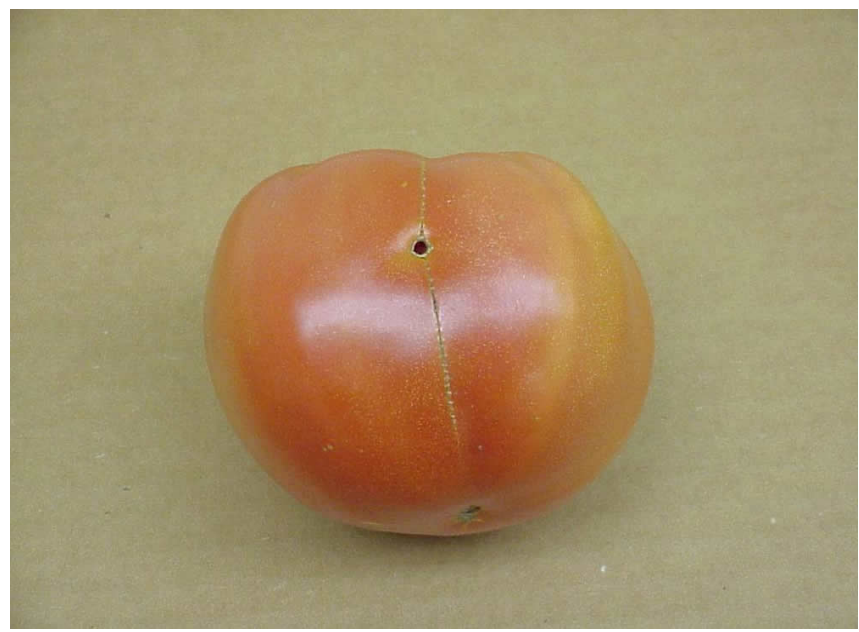

Figure 41. Zippering with open hole in fruit. 